\title{
Raised 5-hydroxytryptamine concentrations in enterochromaffin cells in adult coeliac disease
}

\author{
L ENERBÄCK,${ }^{*}$ C HALLERT,$\dagger K$ NORRBY $\ddagger$ \\ From the $\ddagger$ Departments of Pathology, and †Internal Medicine, University of Linköping, and *Department of \\ Pathology, Sahlgrenska Hospital, University of Göteborg, Sweden
}

SUMMARY We measured cytofluorometrically the concentration of 5-hydroxytryptamine (5-HT, serotonin) of individual enterochromaffin (EC) cells in adult coeliac and non-coeliac small intestinal mucosa. The distributions of 5-HT concentration within populations of EC cells in control and coeliac mucosae were log normal and thus contained one single population of EC cells. The median 5-HT concentration per EC cell, and the number of EC cells both increased in coeliac disease, but showed signs of normalisation when gluten was withdrawn from the diet. The results indicate that, besides inducing EC cell hyperplasia, gluten is capable of producing reversible changes in functions of EC cells in adult coeliac disease.

There is substantial evidence to suggest enhanced metabolism of 5-hydroxytryptamine (5-HT, serotonin) as a typical feature of coeliac disease. Untreated coeliacs have a consistent rise in blood of $5-\mathrm{HT}^{12}$ and they regularly excrete in the urine increased amounts of 5-hydroxyindoleacetic acid (5-HIAA),${ }^{34}$ the major 5-HT metabolite.

The underlying defect is likely to reside in the small intestinal mucosa, where increased tissue concentrations of 5-HT have been demonstrated in untreated coeliac disease. ${ }^{56}$ In human gut mucosa, 5-HT is formed and stored by the enterochromaffin (EC) cells, and the observation of EC cell hyperplasia in the damaged coeliac mucosa, ${ }^{67}$ apparently related to the noxious effect of gluten and the degree of enteropathy, ${ }^{6}$ has been taken to assume that EC cell hyperplasia accounts for the abnormalities in 5-HT metabolism in coeliac disease.

Considering the marked remodelling of the untreated coeliac mucosa ${ }^{8}$ there are obvious problems inherent in assessing alterations in cell numbers per unit area or length of mucosa. To gain further insight into the role of EC cells in coeliac disease we have studied their 5-HT concentration by means of a cytofluorometric method permitting the quantitative analysis of 5-HT in individual cells and the distribution in cell populations of biopsy specimens.

Accepted for publication 15 December 1982

\section{Patients and methods}

PATIENTS

During a 12 -month period 30 adults ( 20 women and 10 men at a mean age of 48 , range $21-73$ yr) underwent small intestinal biopsy in the investigation of possible coeliac disease in the Gastrointestinal Unit, Department of Internal Medicine, Regional Hospital, Linköping. Ten of them (mean age 50, range $30-69 \mathrm{yr}$ ) turned out to have severe duodenojejunal lesions (grade III or IV according to the classification of Alexander ${ }^{9}$ ), and fulfilling strict diagnostic criteria based on small gut morphology and clinical data discussed in detail elsewhere,${ }^{10}$ they were considered to have coeliac disease. All showed steatorrhoea (31-65 mmol/day on a $100 \mathrm{~g}$ fat diet; normal less than $20 \mathrm{mmol} /$ day), and all but one had low serum folate.

The remaining 20 patients showed no (grade I) or slight (grade II) abnormalities in the mucosal morphology, and in the absence of other signs of coeliac disease they were regarded as non-coeliacs. The indication for biopsy in these patients were heredity for coeliac disease in two, lactose intolerance in two, and non-specific gastrointestinal dysfunction in $\mathbf{1 6 .}$

BIOPSY TECHNIQUE AND HISTOPATHOLOGY

Biopsy specimens were obtained from the jejunum close to the duodenojejunal junction by means of a Watson capsule under fluoroscopic control. The 
biopsy was placed in saline, examined by stereomicroscopy and divided into two equal parts. One of these was fixed in $4 \%$ neutral buffered formaldehyde, embedded in methacrylate and sectioned at $3 \mu \mathrm{m}$. Sections were stained with haematoxylin and eosin, by van Gieson's method and by the PAS method. Microscopic assessment was done with regard to alterations characteristic for coeliac disease, ${ }^{11-13}$ and the specimens were classified according to Alexander, ${ }^{9}$ considering both stereological and histological features. The other half of the biopsy was freeze-dried (see below).

\section{COUNTING OF EC CELLS}

The cells were visualised in sections of methacrylate embedded tissue with an alkaline diazo coupling using fast Garnet GBC. ${ }^{14}$ The number of EC cells was counted per unit length $(710 \mu \mathrm{m})$ of muscularis mucosae.

\section{FLUORESCENCE HISTOCHEMISTRY}

5-HT was demonstrated histochemically with the fluorescent formaldehyde reaction according to Falck and Hillarp. ${ }^{15}$ Half the jejunal biopsy was quick-frozen in propane cooled by liquid nitrogen and freeze-dried for $48 \mathrm{~h}$ in a tissue dryer (Thermotron-Vacuummeter, Leybold-Heraeus $\mathrm{GmbH}$, Cologne, GFR). The dry tissue pieces were heated with $6 \mathrm{~g}$ dry paraformaldehyde and $100 \mu \mathrm{l}$ water in a $1000 \mathrm{ml}$ reaction vessel for $1 \mathrm{~h}$ at $80^{\circ} \mathrm{C} .^{16}$ The tissue pieces were paraffin embedded in vacuo. Sections were cut at $10 \mu \mathrm{m}$, flattened by heating, mounted in entellan-glycerol $(1: 1)$, and stored in the dark at $4^{\circ} \mathrm{C}$ until measured.

\section{CYTOFLUOROMETRY}

Fluorescence intensities of individual EC cells were measured with a computer-controlled cytofluorometer based on a Leitz MPV II microscope photometer. ${ }^{17}$ The instrument contains two light paths controlled by electromagnetic shutters, one for identifying the cells and the other for fluorescence activation with short time illumination $(40 \mathrm{~ms})$. The EC cells were identified by fluorescence using low intensity transmitted bright field illumination obtained from a smaller mercury burner (Osram HBO $50 \mathrm{~W}$ ) and Schott BG 36 and BG 3 glass filters (5 and $3 \mathrm{~mm}$ thick). For fluorescence measurements a xenon lamp was used (Osram XBO $75 \mathrm{~W} / 2$ ), incident type of illumination and with filters and optical conditions as described previously. ${ }^{16} \mathrm{~A}$ measuring diaphragm with a diameter of $5 \mathrm{~mm}$ corresponding to a diameter of $20 \mu \mathrm{m}$ in the object plane with the $\times 63$ phase contrast objective was used. The measuring diaphragm was large enough to include the bodies of EC cells while the slender processes usually were not included. Recording of fading rates of individual EC cells during illumination with the mercury 은 burner showed a fading of 10 to $20 \%$ during $20 \mathrm{~s}$ illumination. This was the average illumination time $\stackrel{0}{9}$ of an EC cell before measurement. In each sample $\bar{c}$ 100 EC cells were measured according to a standardised procedure aiming at representative sampling. $\frac{\bar{\rho}}{\bar{D}}$ The short illumination time by the activating lamp $\stackrel{\mathbb{Q}}{\Omega}$ $(40 \mathrm{~ms})$ did not result in any additional fading. The \& variation in fluorescence values caused by fading was thus of the order of $5 \%$. A uranyl glass was used as an instrumental standard and the fluorescence $\vec{\omega}$ values, corrected for background fluorescence of the o. tissue, were expressed as arbitrary "uranyl units". Computation of fluorescence values into corrected $\dot{\omega}$ uranyl units, statistical treatment and histogram of generation was performed by the computer.

RELATION BETWEEN FLUORESCENCE INTENSITY 음 AND CONCENTRATION OF 5-HT

Experiments using amine-containing protein drop- $\bar{z}$

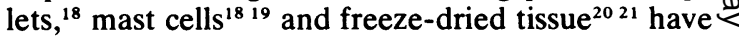
established that formaldehyde-induced fluorescence $\overrightarrow{0}$ can be used for cytofluorometric measurement of $\underset{\omega}{\infty}$

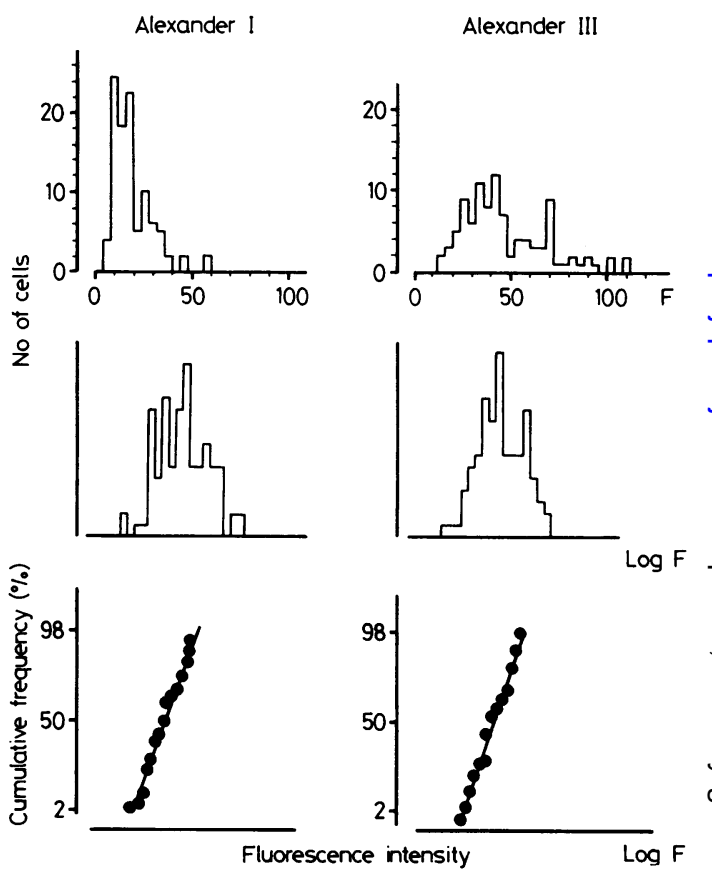

Histograms showing the distributions of 5-HT concentration of EC cells in one non-coeliac and one coeliac mucosa, expressed in untransformed arbitrary uranyl units (top), and in logarithmic values (middle). Probability charts show the cumulative frequencies of the logarithmically transformed values of 5-HT per EC cell (bottom). 
5-HT and catecholamines. In protein models there is a curved relation between fluorescence intensity and concentration of 5-HT at high concentrations of fluorophor. ${ }^{18}$ Also in mast cells there was a slightly curved relation between fluorescence intensity and 5-HT content measured with an independent biochemical method, within a wide range of 5-HT concentration, obtained by induced uptake of 5-HT. ${ }^{16}$ The reaction conditions used in this study have been shown to result in very small variations in fluorescence yield and have been used extensively for measurement of 5-HT in mast cells under a variety of experimental conditions. In the $10 \mu \mathrm{m}$ sections the measuring diaphragm included an EC cell body sectioned along its longitudinal axis. The thickness of the cells is larger than the section thickness which means that the fluorescence intensity is a measure of 5-HT concentration rather than total cellular 5-HT content. Fluorescence intensity, expressed as arbitrary uranyl units was thus used as a relative measure of the $5-\mathrm{HT}$ concentration of the EC cells.

\section{STATISTICS}

The significance of the difference between two means was assessed by Student' $s$ test (including the method of paired comparisons). $\mathrm{p}<0.05$ was considered significant.

\section{Results}

The distribution of fluorescence intensities (proportional to 5-HT concentration) within populations of EC cells were positively skewed. When the logarithmic values of EC cell 5-HT fluorescence were plotted on probability charts, the values fell along single straight lines. The results indicated the existence of one single cell population per sample, and $\log$ normal distribution of 5-HT concentration within each cell population, both in controls and coeliacs (Figure).

The 5-HT concentration of individual EC cells was markedly increased in untreated coeliac patients as was the number of EC cells per unit length of mucosa (Table 1). An indirect measure of the "total EC cell 5-HT content", obtained from the median 5-HT concentration per cell multiplied by the number of EC cells per unit length of mucosa, was also markedly increased in coeliac patients (Table 1). No correlation was found between the median 5-HT concentration per EC cell and the number of EC cells per unit length of mucosa except for speci-

Table 1 Number of patients (in parentheses), morphological type of mucosal lesion (grading according to Alexander), number of EC cells per unit length mucosa (nECC), median 5-HT fuorescence of 100 EC cells (m5-HT), and "total EC cell 5-HT content" $(n E C C \times m 5-H T)$ per unit length mucosa

\begin{tabular}{|c|c|c|c|}
\hline \multirow{2}{*}{$\begin{array}{l}\text { Morphological } \\
\text { grade }\end{array}$} & \multicolumn{3}{|c|}{ Means $\pm S E M$} \\
\hline & $n E C C$ & $m 5-H T$ & “total 5-HT" \\
\hline $\left.\begin{array}{l}\text { II } \\
\text { III } \\
\text { IV }\end{array} \begin{array}{l}7 \\
4 \\
(6)\end{array}\right)$ & $\begin{array}{l}1.02 \pm 0.20 \\
1.73 \pm 0.54 \\
3.83 \pm 0.78 \\
2.98 \pm 0.67\end{array}$ & $\begin{array}{l}14.22 \pm 1.42 \\
15.71 \pm 1.63 \\
30.45 \pm 1.84 \\
21.98 \pm 2.02\end{array}$ & $\begin{aligned} 16.00 & \pm 3.92 \\
26.10 & \pm 7.64 \\
120.50 & \pm 30.47 \\
65.00 & \pm 14.34\end{aligned}$ \\
\hline
\end{tabular}

nECC: I $v$ III $\mathrm{p}<0.001 ;$ I $v$ IV $\mathrm{p}<0.002$.

m5-HT: I $v$ III $\mathrm{p}<0.001 ;$ I $v$ IV $\mathrm{p}<0.01$; II $v$ III $\mathrm{p}<0.001 ;$ II $v$ IV $\mathrm{p}<0.003$; III $v$ IV $\mathrm{p}<0.02$

"total 5-HT": I $v$ III $\mathrm{p}<0.001$; I $v$ IV $\mathrm{p}<0.001$; II $v$ III $\mathrm{p}<0.001$; II $v$ IV $\mathrm{p}<0.03$.

Table 2 Effect of the gluten-free diet on mucosal morphology (grading according to Alexander), number of EC cells per unit length mucosa (nECC), median 5-HT fuorescence of 100 EC cells (m5-HT), and "total EC cell 5-HT content" (from $n E C C \times m 5-H T)$ per unit length mucosa. Using the method of paired comparisons $n E C C(p<0.05), m 5-H T(p<0.001)$, and "total 5-HT" $(p<0.005)$ were all found to be reduced as an effect of the gluten-free diet

\begin{tabular}{|c|c|c|c|c|c|}
\hline Case No & $\begin{array}{l}\text { Morphological } \\
\text { grade }\end{array}$ & $\begin{array}{l}\text { Diet } \\
\text { (months) }\end{array}$ & $n E C C$ & $m 5-H T$ & "total 5-HT" \\
\hline 1 & $\underset{\text { II }}{\text { IV }}$ & 9 & $\begin{array}{l}3 \cdot 6 \\
1 \cdot 5\end{array}$ & $\begin{array}{l}24 \cdot 5 \\
11 \cdot 5\end{array}$ & $\begin{array}{l}88 \\
17\end{array}$ \\
\hline 2 & $\begin{array}{r}\text { III } \\
\text { II }\end{array}$ & 15 & $\begin{array}{l}4 \cdot 8 \\
4 \cdot 4\end{array}$ & $\begin{array}{l}34 \cdot 0 \\
16 \cdot 2\end{array}$ & $\begin{array}{r}163 \\
71\end{array}$ \\
\hline 3 & III & 26 & $\begin{array}{l}2 \cdot 5 \\
1 \cdot 4\end{array}$ & $\begin{array}{l}26 \cdot 2 \\
16 \cdot 2\end{array}$ & $\begin{array}{l}66 \\
23\end{array}$ \\
\hline 4 & IV & 33 & $\begin{array}{l}3 \cdot 3 \\
2 \cdot 9\end{array}$ & $\begin{array}{l}28 \cdot 0 \\
17 \cdot 0\end{array}$ & $\begin{array}{l}92 \\
50\end{array}$ \\
\hline
\end{tabular}


mens of morphological group III where $r=0.932$.

In the untreated coeliac mucosa an increased number of EC cells per unit length of mucosa was seen (Table 1). There was no significant difference between coeliacs showing grade III and grade IV lesions.

So far four patients have been examined in remission following dietary gluten withdrawal. Apart from evident signs of morphological recovery in the duodenojejunal mucosa there was reduction in the number of EC cells per unit length of mucosa as well as in their 5-HT concentration (Table 2) accounting for the observed fall in the "total EC cell 5-HT content".

Chronic enteritis was observed in seven of the 13 biopsies of non-coeliac mucosae of grade I. The presence of inflammation did not affect the 5-HT concentration or the number of EC cells. There were no differences relating to sex and age in any of the studied variables.

\section{Discussion}

Our study shows that increased 5-HT concentration in the damaged coeliac mucosa is related both to an increased 5-HT concentration within these cells and to increased number of EC cells per unit length of muscularis mucosae. The results suggest that both abnormalities are inherent features of the coeliac enteropathy and may return to normal when gluten is withdrawn from the diet.

The physiological role of the EC cells is not fully understood. However, 5-HT is released into the gut lumen following various mechanical and chemical stimuli, and 5-HT has long been thought to have a role in the regulation of intestinal peristalsis. ${ }^{22}$ More recent findings indicate that the secretion of 5-HT from these cells may be under neural influence and effected by efferent sympathetic fibres in the vagus nerve. ${ }^{212324}$

In the light of our observations and those made by others on raised concentrations of blood 5-HT and urinary 5-HIAA, there are reasons to suggest an increased rate of synthesis, storage and release of 5-HT from the EC cells in untreated coeliac disease. Whether or not this is of pathogenetic significance for the development of various features of the disease remains to be elucidated. However, regarding the crypt hyperplasia and the shortened cell cycle time seen in most untreated coeliacs, ${ }^{25}$ it is interesting that 5-HT injected intraperitoneally is reported capable of inducing similar reactions in the rat jejunal mucosa. ${ }^{26}$ The observation of Sjölund $e t a l^{6}$ that EC cells are restricted to the basal portion of the crypts close to the compartment of the stem cells and the proliferating enteroblasts ${ }^{27}$ is noteworthy in this context.

The number of EC cells per unit volume of $\frac{\stackrel{2}{\circ}}{\circ}$ mucosa in coeliac disease may be difficult to count accurately due to intestinal crypt hyperplasia and, $\stackrel{\vec{\rho}}{\overrightarrow{3}}$ therefore, an abnormal ratio of crypts per unito length in patients with coeliac disease as compared등 to controls. In a recent study ${ }^{6}$ no correlation was $\overline{\bar{s}}$ found between the EC cell count and the 5-HT con- $\vec{\otimes}$ centration (per mg protein) in the individual biopsy specimens. This may have been due to a dilution ${ }^{\infty}$ effect caused by the crypt hyperplasia in coeliac dis- $\vec{O}$ ease. Clearly, our in situ histochemical approach $\vec{\overrightarrow{ }}$ which is unaffected by any inaccuracy in the enu- $\omega$ meration of EC cells has a definite advantage in describing the EC cell population with regard to 5-HT concentration in coeliac disease Hyperplasia of the EC cell-system, increased storage of 5-HT in these cells and an increased rate $₫$ of secretion of 5-HT from them appear to be ao remarkably constant phenomenon in coeliac dis- ease. Further studies are warranted to see whether 3 these features and the alleged reversibility on the gluten-free diet also apply to the crypt hypoplasia $\vec{c}$ variety and other varieties of the coeliacos enteropathy. ${ }^{11}$ Measurements of the cellular concentration of 5-HT in biopsy specimens, as intro-o duced here, may be of value for such studies.

This research was supported by the Swedish Medical\% Research Council, Projects 2235 and 5942, and을 Östergötland County Research Council.

\section{References}

' Pimparkar BD, Senesky D, Kalser MH. Blood serotonin in non tropical sprue. Gastroenterology 1961;40:504-6.

${ }^{2}$ Hallert C. Clinical aspects of adult coeliac disease. Linköping University Medical Dissertations, 1981:123.

${ }^{3}$ Kowlessar DW, Williams RC, Law DH, Sleisenger MH. Urinary $\varnothing$ excretion of 5-hydroxyindoleacetic acid in diarrheal states with special reference to nontropical sprue. $N$ Engl J Med 응 1958;259:340-1.

${ }^{4}$ Challacombe DN, Brown GA, Black SC, Storrie MH. Increased excretion of 5-hydroxyindoleacetic acid in urine of children with untreated coeliac disease. Arch Dis Child 1972;47:442-8. N

5 Challacombe DN, Dawkins PD, Baker P. Increased tissue con- G centrations of 5-hydroxytryptamine in the duodenal mucosa of $\mathrm{N}$ patients with coeliac disease. Gut 1977;18:882-6.

- Sjölund K, Alumets J, Berg N-O, Hâkanson R, Sundler F. W Enteropathy of coeliac disease in adults: increased number of $O$ enterochromaffin cells in the duodenal mucosa. Gut 1982;23:42-8.

' Challacombe DN, Robertson K. Enterochromafin cells in the duodenal mucosa of children with coeliac disease. Gut $?^{+}$ 1977;18:373-6.

${ }^{8}$ Wright NA, Watson A, Morley A, Appleton D, Marks J, Douglas $A$. The cell cycle time in the flat (avillous) mucosa of the $\mathbb{\mathbb { D }}$ human small intestine. Gut 1973;14:603-6.

- Alexander JOD. The small intestine in dermatitis herpetiformis. $\stackrel{\mathbb{Q}}{\Omega}$ In: Rook A, ed. Major problems in dermatology Vol 4. London: WB Saunders, 1975:236-80. 
${ }^{10}$ Hallert C, Gotthard R, Norrby K, Walan A. On the prevalence of adult coeliac disease in Sweden. Scand J Gastroenterol 1981;16:257-61.

"Whitehead R. Mucosal biopsy of the gastrointestinal tract. In: Bennington JL, ed. Major problems in pathology Vol 3. London: WB Saunders, 1979:88-103.

${ }^{12}$ Ferguson A. Intraepithelial lymphocytes of the small intestine. Gut 1977;18:921-37.

${ }^{13}$ Morson BC, Dawson IMP. Gastrointestinal pathology. Oxford: Blackwell, 1979:344-61.

${ }^{14}$ Enerbäck L. Mast cells in carcinoid tumours. Distribution, histochemical properties and 5-hydroxytryptamine content. Acto Pathol Microbiol Scand 1965;64:491-505.

is Falck B, Hillarp N- $\AA$, Thieme G, Torp A. Fluorescence of catecholamines and related compounds condensed with formaldehyde. J Histochem Cytochem 1962;10:348-54.

${ }^{16}$ Enerbäck L, Gustafsson B, Mellblom L. Cytofluorometric quantitation of 5-hydroxytryptamine in mast cells: An improved method for the formaldehyde condensation reaction. $J$ Histochem Cytochem 1977;25:32-41.

17 Enerbäck L, Rundquist I. DNA distribution of mast cell populations of growing rats. Histochemistry 1981;71:521-31.

${ }^{18}$ Ritzén M. Quantitative fluorescence microspectrophotometry of 5-hydroxytryptamine-formaldehyde products in models and in mast cells. Exp Cell Res 1966;45:178-94.

19 Enerbäck L, Jarlstedt J. A cytofluorometric and radiochemical analysis of the uptake and turnover of 5-hydroxytryptamine in mast cells. J Histochem Cytochem 1975;23:128-35.

${ }^{20}$ Jonsson G. Quantitation of fluorescence of biogenic monoamines. Progr Histochem Cytochem 1971;2:229-344.
${ }^{21}$ Ahlman H, Dahlström A, Kewenter J, Lundberg J. Vagal influence on serotonin concentration in enterochromaffin cells in the cat. Acta Physiol Scand 1976;97:362-8.

${ }^{22}$ Bülbring $E$. The intrinsic nervous system of the intestine and local effects of 5-hydroxytryptamine. In: Kety SS, Elkes J, eds. Regional neurochemistry. Oxford: Pergamon Press Ltd, 1961:437-41.

${ }^{23}$ Hohenleitner F, Tansy M, Goldner R. Effect of vagal stimulation on duodenal serotonin in the guinea-pig. $J$ Pharmacol Sci 1971;60:471-2.

${ }^{24}$ Lundberg JM, Ahlman H, Dahlström A, Kewenter J. Catecholamine containing nerve fibers in the human abdominal vagus. Gastroenterology 1976;70:516-22.

${ }^{2 s}$ Watson AJ, Wright NA, Appleton DR. Cell proliferation in normal, convoluted, and avillous small-intestinal mucosae of man. In: Appleton DR, Sunter JP, Watson AJ, eds. Cell proliferation in the gastrointestinal tract. Tunbridge Wells: Pitman Medical, 1980:350-63.

${ }^{26}$ Tutton PJM. The influence of serotonin on crypt cell proliferation in the jejunum of rat. Virchows Arch (Cell Pathol) 1974;16:79-87.

${ }^{27}$ Potten CS. Stem cells in small-intestinal crypts. In: Appleton DR, Sunter JP, Watson AJ, eds. Cell proliferation in the gastrointestinal tract. Tunbridge Wells: Pitman Medical, 1980:141-54.

Requests for reprints to: Klas Norrby, Department of Pathology II, University of Linköping, S-581 85 Linköping, Sweden. 